\title{
Case Report of a Brain-Injured Child; Illustrating a Teamwork Approach to Rehabilitation \\ by
}

F. T. LUBINSKY. B.A.Log.(Rand) - Speech Therapist.

In collaboration with; MR. C. O. OVENDALE.

M.B.B.CH.(Rand) F.R.C.S. (Eng.) - Surgical Registrar.

A. BURR. M.C.S.P. - Physiotherapist.

J. SPROTT. O.T.(Rand). - Occupational Therapist.

On the $25 / 1 / 62$ a boy aged 11 years, whom we shall refer to as John, was admitted to the Transvaal Memorial Hospital. He had been knocked down by a motor vehicle, and was practically moribund. At that time, there was very little hope for his recovery. Six weeks later when he regained consciousness he had a paralysis of the right side. He ate and slept but showed very litte interest in his environment. He used to cry and laugh raucously from time to time, other than that he did not vocalise at all. At this stage he was being treated by the Physiotherapist; his physical condition improved and he was able to manipulate his hands and to walk with a limp. He then received Occupational Therapy. John's response to stimuli improved gradually, and three months after the accident the Speech Therapist was called in to treat him. He made remarkable progress and his speech came back completely after four weeks of intensive therapy. In order to present a comprehensive picture of the factors which contributed to John's rehabilitation, I am including reports of his treatment by the Surgical Registrar in charge of the case, the Physiotherapist, the Occupational Therapist and the Speech Therapist who treated him. The importance of teamwork in this case can not be over emphasised.

\section{SURGEON'S REPORT.}

On admission it was apparent that John had suffered a very severe head injury. He was deeply unconscious, and his breathing was sterterous. General examination revealed a laceration of his scalp and a simple fracture of his right clavicle. There were no other external injuries.

Examination of his central nervous system showed marked brain damage, since he was deeply unconscious, had a partial paralysis of his right arm and leg, and had a dilated right pupil, which did not react to light. There was spasticity of the right arm. On testing his Babinsky reflexes, both great toes were upgoing.

X-Rays, which were of poor quality due to the patient's condition, showed no fractures of his skull or jaw. There was some bruising of his left lung and a possibility of a fracture in the left 6 th and 7 th ribs.

$\mathrm{He}$ was treated conservatively by hypothermia, hiberration, antibiotics and general nursing care. The next morning his condition was unchanged, but due to his poor respiration and the moist sounds in his lungs a tracheotomy was decided upon. This was done under local anaesthesia on 26th January, 1962.

On 29th January, 1962, his condition was still the same and he remained deeply unconscious. Further X-Rays were therefore done, which showed no fracture in the skull or lumbar spine, and a cerebral anteriogram showed no evidence of an intracranial spaceoccupying lesion.

His general condition improved, but he remained deeply unconscious and paralysed on his right side for many weeks. The tracheotomy tube was removed after about one month. About five weeks after the accident he started swallowing and so could be fed by spoon instead of via a tube.

$\mathrm{He}$ then rapidly improved and was soon running about the ward, but still had complete aphasia.

\section{PHYSIOTHERAPIST'S REPORT.}

When treatment was commenced on John, the boy was unconscious and spastic, both feet being plantaflexed and the legs adducted The arms, wrists and fingers were flexed 
and the shoulders adducted. The initial treatment therefore, consisted of purely passive movements to all limbs. It was noticed that his right side was more spastic than his left, the arm being particularly so, and he protested more on having the right elbow extended than any other joint.

When he began to regain consciousness he became more and more co-operative and passive movements gave way to active movements till ultimately we were able to get him walking, although the right side still remained spastic, and he walked in a similar manner to any other hemiplegic. He never spoke but understood what we asked him to do and still protested when the right elbow was extended. This was afterwards put in plaster and when the plaster was removed some weeks later the spasticity in the arm was very much less. The general spastic condition became rapidly better and within a short while he was walking normally and only had a slight tension in the right elbow flexors. At this stage the Physiotherapy was stopped as it was felt that he would now do better at Occupational Therapy.

\section{OCCUPATIONAL THERAPIST'S REPORT.}

John started receiving Occupational Therapy when he started walking. However, for some time before this the Occupational Therapist had made contact with him in the ward.

The assessment on his first treatment revealed an extremely low concentration span, aphasia, and an urge to explore. He also continually tried to go out of the room during the first three or four treatments. John had a pleasant personality. On the physical side he showed general weakness on the right side of his body and his right elbow was kept in a slightly flexed position.

Later testing showed lack of colour and space perception, some inco-ordination and difficulty in carrying out instructions although he seemed to understand them. It became extremely obvious that although he received and understood most, if not all stimuli given, there was a breakdown in the effector pathway.

Because of the very low concentration span a large variety of simple, easy and quickly accomplished activities had to be found, and it was felt that games were the most satisfactory. Games were also used to produce excitability and thus encourage the use of the one or two sounds he was able to make.

Activities involving blowing — such as soap bubbles - were also used extensively to encourage the movements which the Speech Therapist was trying to obtain. These activities were carried out mainly in groups and it was obvious that John enjoyed being with other children. He showed a great liking for small children and quite happily joined in games with them.

For a certain period each day individual treatment was given. During this time writing, drawing and colouring-in were stressed.

Throughout the time John was being treated continual progress was noticeable. Almost every day some obstacle or difficulty was overcome. After his dramatic recovery of speech his general recovery also seemed to increase more rapidly.

\section{SPEECH THERAPIST'S REPORT.}

I first saw John on the $24 / 4 / 62$. His physical appearance was normal apart from the weakness on his right side. Oral Peripheral examination showed the speech mechanism to be normal, although there was some weakness on the right side. His chewing, sucking and swallowing reflexes were normal, though he could not move his lips or tongue voluntarily when required to do so. Manual manipulation and hand-eye co-ordination were poor. He had been right handed previous to the accident. He often smiled or laughed for no apparent reason. His laughter had a bizarre sound and could be heard right across the ward. In the initial interview I could get no response from him other than his laugh.

The nurse in his ward told me that he needed constant surveillance and was fond of wandering around the Hospital. The staff were very fond of him and he was popular with the other patients. It is possible that he had some disturbance of social perception as he reacted in the same pleasant manner to everybody. It was impossible to get a family history, as John's mother did not keep appointments which were made for her to see me. He had been in Standard Four at school and was allegedly of "normal" intelligence before the accident. He used to be a disturbing influence in the class, often inciting the other children to mischief.

During subsequent sessions in the first week of therapy I found him mobile in attention and activity. He was unduly attracted 
by the doings of others and by the presence of normally inconspicuous background stimuli. His concentration span was short. John's perception of his environment fluctuated. He was able to match object to object and he could copy a simple pattern with his left hand. He reacted strongly to food and would sit down and wait to be served as soon as he saw it arriving. He apparently lacked the ability to integrate his experiences and to organise space and form.

John's problem was one of expressive aphasia with verbal apraxia and agraphia. He did not verbalise at all. The nurses said that he grunted occasionally, but during the first week of therapy I did not hear him vocalise. Upon being shown a noise making toy cow, he tried to imitate the sound which it made "moo", by moving his lips slightly without any voice. He used some gestures for communication and was able to respond to simple commands. In the field of auditory perception, there appeared to be some disturbance, which manifested itself in distractability and erratic responses. He appeared to be suffering from some limitations of broad conceptualization and generalization. John displayed emotional lability and would burst out laughing periodically. As his condition improved he showed concern with orderliness. He used to help the nurses to tidy the ward. Naturally, this helped to make him well liked.

\section{Therapy}

The aims of therapy were:-

(1) To establish a good relationship with John, giving him a constant, secure social contact.

(2) To help him to acquire more language, and to integrate his experiences while controlling his behaviour.

(3) To encourage a desire for communication.

(4) To stimulate the production of speech.

John had therapy four days a week, sometimes twice a day. To counteract emotional lability and distractability I tried to be consistently calm and accepting, though firm. $\mathrm{He}$ was only given one stimulus at a time to help him to integrate this experience. Therapeutic sessions lasted till he showed fatigue. At the commencement of therapy John was unco-operative and displayed little interest. He would get up and walk out of the room.
Every day brought some improvement and gradually he took more interest in the therapy. His concentration span improved and he showed less fatigue. His environment became more meaningful to him and he could relate more effectively to it. During the second week of therapy John was taking an interest in the welfare of the other patients. Many of them were bedridden and he was very helpful to them. His understanding had improved sufficiently for him to do errands for them. The fact that John was in such a warm friendly environment contributed in a large measure to his improvement. The group work in Occupational Therapy had done much to improve his social relationships. The nursing staff also helped a great deal in making John socially well adjusted. They gave him physical tasks which he could accomplish successfully. I asked them to use simple language when talking to John without demanding a response from him, and they were most co-operative. He was now using more gestures to indicate his wants. I did not inhibit this as I felt that it was helping him to make contact with others and to overcome his frustration in being unable to communicate.

John was given play situations structured in such a way that communication was important. He was required to nod his head and say "uh" for "yes" and "uh-uh" for "no". To begin with he just nodded his head. After being given a lot of auditory stimulation for the sound, he accompanied the nod with "uh". He said "uh" meaningfully for the first time on $9 / 5 / 62$.

I discussed this with the nurses and the Occupational Therapist, and asked them to reinforce this sound as much as possible. Again they were extremely co-operative.

In the third week John's communication through gestures was greatly improved as well as his understanding. The other patients used to talk to him and he would grin or laugh at them and say "uh". He was now ready for auditory stimulation of simple words, accompanied by objects and pictures, as well as co-operative and competitive play with language stimulation. Words with labial sounds were emphasized. In addition, lip, tongue and breathing exercises were given in the form of games. He could now approximate his lips when blowing, and tongue movements were improving: The MotoKinesthetic method was used to teach him to 
say "ma ma". the first day he did not respond but on the second day, he said "ma ma" voluntarily. This was on the $17 / 5 / 62$. He was thrilled and once again I elicited the staff's co-operation in order to reinforce this word. He went around saying it the whole of that day. The next day he was able to say "ba ba" when his mouth was stimulated Moto-Kinesthetically. On the $22 / 5 / 62$ his speech returned dramatically. He was suddenly able to speak English and Afrikaans fluently. It was as if being able to say those two words had opened the door to language and speech!

\section{FOLLOW-UP REPORT.}

John was discharged from Hospital on $1 / 6 / 62$. He was seen in the Out-Patients Department on the $16 / 7 / 62$. He was talking well and intelligently, though he had no memory for recent events. When reminded, however, he remembered everything in detail.

On physical examination it was found that he had full passive movement in the right arm and normal reflexes, although all muscle power was slightly reduced. His legs were weak.

His mother seemed to be concerned about him and he was obviously happy to be home again.

\section{SCHOOLING.}

John has gone back to Standard 4. His work is not up to the standard of his classmates, and as a result he needs individual tuition. He is scared of being laughed at and is very shy and quiet in class; this shows a marked difference in his personality, as he used to be very lively and interested in everything. In spite of this change, he has friends and is not rejected by the other boys. The teacher finds him very helpful in class. Occasionally he still laughs for no reason. $\mathrm{He}$ speaks English and Afrikaans fluently, although his speech is slightly indistinct at times. He. has settled down in the class and is not restless. He attempts to do all the work although he often cannot manage it.

\section{SUMMARY.}

In summary, the above report constitutes the case reports of a child who has had traumatic brain damage. His rehabilitation programme has been described from the viewpoint of the Surgeon, the Physiotherapist, the Occupational Therapist and the Speech Therapist. These specialists worked together in close co-operation with the medical and nursing staff. John's progress was watched and compared in different spheres of activity. In my opinion John's remarkable recovery was due to the intensive treatment which he received on all levels, and to the teamwork approach. Because of the co-operation of the staff it was possible to manipulate his environment successfully. They all helped to create an atmosphere which was conducive to his relearning of speech and language. John is still attending the hospital regularly as an outpatient and he will probably reach his maximum recovery in several months time. It is hoped that with the passage of time when he recovers from the emotional setback, he will become a well integrated member of society.

I should like to reaffirm that rehabilitation can only be achieved with the co-operation of all the specialists involved. Mutual knowledge of each other's contribution and role is necessary for successful co-operation.

\section{OPSOMMING.}

Die voorafgaande artikel is ' $n$ gevals rapport van 'n kind wat 'n wondende breinbesering opgedoen het. Sy rehabilitasieprogram is gesien vanuit die oogpunt van die Sjirurg, die Fisioterapeute, die Beroepsterapeute en die Spraakterapeute. Die spesialiteite het in noue samewerking met die mediese personeel en die verpleegsters behandling toegedien. Die kind se vordering is dopgehou en vergelyk deur die persone wat hom behandel het. Na die skrywer se mening is sy merkwaardige herstel te danke aan die intensiewe behandeling wat hy ontvang het op die verskillende vlakke en as gevolg van die span werk. Met behulp van die samewerking van die personeel is sy omgewing suksesvol verander. Almal het bygedra om ' $n$ atmosfeer, wat die leer van spraak en taal bevorder, te skep. Die kind besoek nog die hospitaal as 'n buitepasiënt en sal waarskynlik binne 'n paar maande sy maksimum herstellingspeil bereik. Ons vertrou dat hy met die tyd van die emosionele terugslag sal herstel en dan 'n goed aangepaste lid van sy sosiale omgewing sal word.

(I wish to thank the Superintendent of the Johannesburg General Hospital, as well as the Supervisor of the ..Hospital Speech Therapy Department for their permission in allowing us to publish this case history.) 